\title{
Correction
}

\section{Development and evaluation of scheme for serotyping Gardnerella vaginalis}

We regret that an error occurred in table 1 of this paper by CA Ison, DG Harvey, A Tanna, and CSF Easmon (June issue, p 198). The correct table is shown below.
In the Results section of the text, on the same page as table 1, four lines from the bottom of the second column, the score showing that each observer had found that the strain gave at least a weak reaction should have been $<2$, not 3 .

Table 1 Selection of criteria for evaluating serotyping

\begin{tabular}{|c|c|c|c|c|c|c|}
\hline \multirow{2}{*}{$\begin{array}{l}\text { Sum of } \\
\text { scores }\end{array}$} & \multicolumn{3}{|c|}{$\begin{array}{l}\text { Minimum } \\
\text { individual scores* } \\
\text { by observers: }\end{array}$} & \multirow{2}{*}{$\begin{array}{l}\text { No }(\%) \text { of isolates } \\
\text { typed } \\
(n=91)\end{array}$} & \multirow{2}{*}{$\begin{array}{l}\text { No (\%) of isolates } \\
\text { reactive with } \\
\text { single antiserum }\end{array}$} & \multirow{2}{*}{$\begin{array}{l}\text { Total no } \\
\text { of serogroups }\end{array}$} \\
\hline & $l$ & 2 & 3 & & & \\
\hline $\begin{array}{l}>5 \\
>4 \\
>3 \\
>2 \\
>1\end{array}$ & $\begin{array}{l}2 \\
2 \\
1 \\
1 \\
1\end{array}$ & $\begin{array}{l}2 \\
2 \\
1 \\
1 \\
1\end{array}$ & $\begin{array}{l}2 \\
1 \\
2 \\
1 \\
0\end{array}$ & $\begin{array}{l}39(43) \\
57(63) \\
65(71) \\
79(87) \\
84(92)\end{array}$ & $\begin{array}{l}34(37) \\
49(54) \\
50(55) \\
52(57) \\
45(50)\end{array}$ & $\begin{array}{l}12 \\
14 \\
16 \\
20 \\
28\end{array}$ \\
\hline
\end{tabular}

${ }^{*} 0=$ negative, 1 = weak reaction (less than that of control), $2=$ strong reaction (equal or greater than that of control).

Antibody dilution $=1: 10000$.

\section{Notices}

Organisers of meetings who wish to insert notices should send details to the editor (address on the inside front cover) at least eight months before the date of the meeting or six months before the closing date for application.

Fifth Zagazig international conference of dermatology and venereology

The fifth Zagazig international conference of dermatology and venereology will be held on 6 to 10 February 1988 in Cairo, Egypt.

For further information please contact Professor M Amer, Chairman, Dermatology and Venereology Department, Faculty of Medicine, Zagazig, Egypt.

First conference of the European Society for Chlamydia Research

The first conference of the European Society for Chlamydia Research will be held on 30 May to 1 June 1988 in Bologna, Italy. The main topics will include: epidemiology and preventive measures against chlamydial infections (with $C$ trachomatis and $C$ psittaci) in Europe, biology, clinical manifestations and treatment, immunology and interaction between host and parasite, diagnostic procedures, chlamydial genetics, and vaccine development.
Please contact Dr Roberto Cevenini, Institute of Microbiology, University of Bologna, S Orsola University Hospital, 9 via Massarenti, 40138 Bologna, Italy (tel: 051-341652/302435).

Anglo-Scandinavian conference on sexually transmitted diseases

The Anglo-Scandinavian conference on sexually transmitted diseases will be held on 11 to 13 May 1988 at the Royal Society of Medicine, London.

For information please contact the conference secretariat (Miss Barbara Komoniewska) at the Royal Society of Medicine, 1 Wimpole Street, London W1 (Tel: 014082119 ext: 301).

34th General assembly of the International Union against the Venereal Diseases and Treponematoses (IUVDT)

The 34th general assembly of the IUVDT will be held on 3-4 June 1988 at the Palais de $\frac{\overrightarrow{0}}{3}$ Festivals de Cannes, Cannes, France.

For information please contact $\mathrm{Dr} \mathrm{M}_{1}$ 弄 Waugh, Secretary General of the IUVD1 The General Infirmary at Leeds, Grec $\stackrel{\infty}{=}$ George Street, Leeds LS1 3EX. (Tel: 053 432799).

Spring meeting of the Medical Society for th $\mathrm{N}$ Study of Venereal Diseases (MSSVD)

The spring meeting of the MSSVD will $b$ N held on 30 June to 3 July 1988 at Cambridge England.

For information contact the local organio ser, Dr MR FitzGerald, Addenbrooke' Hospital, Cambridge, CB2 2QQ or the trave ${ }^{-}$ agent, $\mathrm{Mr}$ Peter Davidson, Horncastl Travel Limited, 10 Market Street, New castle-upon-Tyne, NE1 6JF. 